\title{
ASSESSING THE ROLE OF A LIMESTONE QUARRY AS SEDIMENT SOURCE IN A DEVELOPING TROPICAL CATCHMENT
}

\section{SHORT TITLE: ASSESSING SEDIMENT OUTPUTS FROM A QUARRY IN A TROPICAL CATCHMENT}

Fernando Jaramillo*

Department of Physical Geography and Quaternary Geology, Stockholm University.

Bert Bolin Centre for Climate Research, Stockholm University.

SE-106 91, Stockholm

Tel: +468164665

Sweden

fernando.jaramillo@natgeo.su.se

Matthieu Baccard

Department of Civil Engineering and Applied Mechanics, McGill University

817 Sherbrooke St. West, Montreal, PQ, H3A 2K6

Canada

matthieu.baccard@mail.mcgill.ca

Pramenath Narinesingh

Department of Civil and Environmental Engineering, The University of the West Indies, St. Augustine Campus,

Eastern Main Road, St. Augustine,

Trinidad and Tobago

pramenath.narinesingh@sta.uwi.edu

\section{Susan Gaskin}

Department of Civil Engineering and Applied Mechanics, McGill University

817 Sherbrooke St. West, Montreal, PQ, H3A 2K6

Canada

susan.gaskin@mcgill.ca

\section{Vincent Cooper}

Department of Civil and Environmental Engineering, The University of the West Indies, St. Augustine Campus, Eastern Main Road, St. Augustine,

Trinidad and Tobago vincent.cooper@sta.uwi.edu

\section{* Corresponding author}

This article has been accepted for publication and undergone full peer review but has not been through the copyediting, typesetting, pagination and proofreading process, which may lead to differences between this version and the Version of Record. Please cite this article as doi: $10.1002 / l d r .2347$ 


\section{ABSTRACT}

Impact assessments on river systems of the combined effect of bed and suspended sediment loads emitted from quarries are difficult to find. In this study, bed and suspended loads were measured to determine the impact of a 20 ha limestone quarry on the river system of its 5,000 ha steep, diverse Land Use/ Land Cover but mostly forested catchment. A network of hydrologic and sediment monitoring instruments was deployed over the catchment during two separate study periods when sediment loadings were measured from captured storms. Results showed that the quarry stood to make a disproportionately large contribution to the catchment's estimated $2.1 \mathrm{Mg} \mathrm{ha}^{-1} \mathrm{yr}^{-1}$ suspended sediment load. Large storm events contributed most of the loadings with five events supplying $92 \%$ of total loadings at the outlet. A paired method approach to compare suspended sediment loads between two subcatchments showed that during 8 storm events, the quarry yielded between 2 and $49.2 \mathrm{Mg} \mathrm{ha}^{-1}$ per event while the forest never yielded more than $0.1 \mathrm{Mg} \mathrm{ha}^{-1}$. Furthermore, the contribution of sediments from the quarry to bed load was more than $75 \%$ at a section $1.2 \mathrm{~km}$ downstream. Future management activities to reduce sediment and bed loads, not only from this catchment but all others with similar Land Use/ Land Covers, should focus on improving quarry operations. 


\section{INTRODUCTION}

Over the past three centuries, the global demand for construction materials has contributed a large share of the transfers of sediment to the oceans primarily from extracting and construction activities (Douglas, 1991). In 2000, it was estimated that extracting activities alone produced $62,265 \mathrm{Tg}$ of material of which at least two thirds comprised overburden and waste that eventually could end up in the global stream network (Douglas \& Lawson, 2005). In general, the sediment concentration and yield from Land Use/Land Cover (LULC)s of the construction material chain such as construction sites, mines and quarries are considerably higher than those from other LULCs, such as agriculture and forests (Wolman, 1967; Wolman \& Schick, 1967). In a similar way, other activities such as in-stream sand mining (Sadeghi \& Kiani Harchegani, 2012) or LULCs involving the exposure of bare soil such as roads (Cerdà, 2007; Lee et al., 2013), badlands (Cerdà, 1999; Dickie \& Parsons, 2012) and fireaffected land (Cerdà \& Lasanta, 2005; Fernández et al., 2012) also generate high amounts of sediment material to running waters. In the case of quarries, which are at the origin of the construction material chain, it is important to study erosion and sediment transport processes, in-situ and downstream of the source of these sediments (Evans, 2000, Erskine \& Saynor, 2000, Rajaram et al., 2005) in order to understand their role as important pollution sources to both surface and groundwater (Wolman \& Schick, 1967;

Drysdale et al., 2001; Darwish et al., 2011; Qi \& Zhang, 2011; Haile \& Fetene, 2012; Prokop \& Poręba, 2012; Yitbarek et al., 2012; Haregeweyn et al., 2013; Hudson \& Inbar, 2012; Wang \& Shao, 2013). Their study is also necessary for prioritization of soil erosion risk areas for erosion management (Mandal \& Sharda, 2013; Zhao et al., 2013). 
The sediment yield at any point of a given stream network is composed of suspended load and bed load. The suspended load is made up of clays, silts and sands so fine as to be always entrained in suspension that are flushed from upland sources and "washed" through the channel. The river bed load contains generally coarser material (Einstein et al., 1940). In order to assess the sediment yield of a basin, it is necessary to understand the overall sediment budget of a basin and its corresponding sources and sinks. This, since sediment can be temporarily stored in the river bed and resuspended in subsequent storm events or moved as bed load under base flow or low flow (Walling, 1983;

Walling, 1999) and because suspended sediment at the outlet of a catchment is not only comprised of suspended load from hill slope erosion but also from sediment originating from streambed and bank erosion. Sediment originating from in-stream processes can account for as much as two thirds of the total sediment yield from a catchment (Trimble, 1997).

While mobilization yields from LULCs related to the construction material chain can be two (2) to four (4) orders of magnitude greater than natural denudation rates (Rivas et al., 2006), suspended sediment concentrations from these activities can exceed two (2) to ten (10) times those from undisturbed conditions and occasionally up to 100 times more (Walling \& Gregory, 1970). Suspended sediment yields from small areas with construction activities can even reach up to $550 \mathrm{Mg} \mathrm{ha}^{-1} \mathrm{yr}^{-1}$ (Wolman \& Schick, 1967).

A case study on sediment loads from anthropogenic sources can be found in Trinidad and Tobago's (Figure 1a) recent attempt at quantifying and determining the sources and transport dynamics of sediment in the country. This initiative has been motivated in part 
by the threat to the Caroni Swamp; an ecologically diverse coastal wetland named a Ramsar site in 2005, which is hydraulically connected to the Caroni River when it is in spate (Figure 1b) and that can therefore be adversely affected by high sediment loads transported by the river.

Quarrying is currently accompanying the rapid expansion of physical infrastructure and the increased urbanization across the country and it is no doubt partly to blame for the high levels of suspended load in the Caroni River and its tributaries. However, it has been difficult for the authorities to control such emissions, primarily due to lack of data required for their quantification. Additionally, the general heterogeneity of development, both urban and agricultural, makes it difficult to assess the sediment yield that each LULC is contributing.

Overall, this study aims at quantifying the role of a quarry located in the Maracas-Saint Joseph River Catchment (MSJRC) as a main sediment source of both suspended and bed load, and to compare its sediment production estimates with others from representative LULCs in the area (forest and housing construction sites). We seek to examine the initial hypothesis of the community and local scientists that the quarry is the main contributor to sediment pollution in MSJRC. We initially used the Revised Universal Soil Loss Equation - RUSLE (Renard, 1997) to identify the main sources of sediment in the catchment. From the results of that model application, included in Jaramillo (2007), we performed this study to measure the peak Total Suspended Solids (TSS) concentrations from several storm events for these sources and confirmed the quarry as a significant source of suspended load. We further quantified the suspended 
and bed sediment yields and characterized the material from bed and bed load downstream from the discharge of the quarry into the river network of MSJRC. From the information collected, we estimated the impact of the quarry on sediment yields at the outlet of MSJRC.

This study will therefore: 1) complement the few available scientific studies regarding observed and recorded sediment pollution from limestone quarries; 2) shed light on the role of the quarry as a main polluter in the basin; 3 ) permit the quantification of the sediment pollution capacity of the quarry and compare it with other possible emitting sources in the basin; and 4) serve as evidence for the implementation of future regulations and controls for reducing sediment pollution in catchments in Trinidad and Tobago.

\section{MATERIALS AND METHODS}

\section{Site description}

The 5,000 ha MSJRC drains into the Caroni River and is located $16 \mathrm{~km}$ from the island's capital city, Port of Spain (Figure 1c). The terrain with elevations varying between 30 and 937 m.a.s.l, is composed mainly of rugged hills having slopes ranging primarily between $20^{\circ}$ and $30^{\circ}$. The long term average annual rainfall is estimated at 1,592 mm (MALMRTT, 1994). The wet season extends from the beginning of June to December and the dry season covers the period from January to late May. The driest month is March and the wettest periods occur in July and November. The rain bearing clouds are mainly from the northeast and intense rainfall normally occurs in the eastern highlands of the catchment, accounting for high rainfall intensity and duration 
represented by the product $\left(\mathrm{EI}_{30}\right)$ of the total storm energy $(\mathrm{E})$ and its maximum 30minute intensity (I30) (Wischmeier \& Smith, 1978; Renard, 1997) (Figure 2a), which are generally higher than in other studied areas (Vaezi et al., 2010).

The Maracas-Saint Joseph River (MSJR) receives water from two main tributaries, the Loango River to the northwest and the Acono River to the northeast, which in turn, receives water from other tributaries such as the Don Juan River. The northern, upper region of the catchment is covered mainly by forest comprising almost $85 \%$ of its area (Figures $1 \mathrm{c}$ and $2 \mathrm{~b}$ ). As the river moves downstream, at lower elevations the forest becomes interwoven mainly with open land patches for residential use and sustainable agriculture. About $8 \%$ of MSJRC have been urbanized with low density housing. The soils in the catchment (Figure 2c) are mainly composed of loams and clays found in alluvium deposits to the northeast (Brown \& Bally, 1967). Blue limestone reserves are found in the upper part of the Don Juan River subcatchment and currently there is a quarry extracting these reserves for construction purposes. The quarry has an area of about 20 ha including the mining and blasting zones, various storage piles of extracted and processed limestone and other facilities. Sediment traps at various places within the quarry have been provided to reduce sediment loadings reaching the waterway. Despite this, the deterioration of water quality in rivers downstream of the quarry has been blamed on its discharge. This is particularly the case during the wet season even though impacts can also be observed during the dry season.

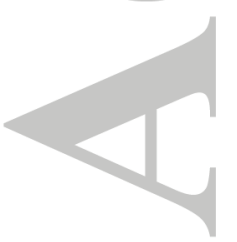

This article is protected by copyright. All rights reserved. 


\section{Suspended sediment yields at MSJRC outlet}

In order to quantify the suspended sediment yield exiting MSJRC, an infrared Optical Backscattering Sensor (OBS) was installed at Location 1 (Lc1) (see Tables 1 and S1) from September 2006 to March 2007 to measure TSS every 10 min (see Figure 1c). The OBS was located alongside a 6820 YSI stage recorder, suspended on the abutment of a bridge, about seven (7) kilometers upstream from the mouth of MSJR on the Caroni

River. The Water and Sewerage Authority of Trinidad and Tobago (WASA) had been operating this station since 1971 . The contributing area at Lc1 is 4,096 hectares.

A total of seventeen sudden tracer (common salt) injection experiments and six (6) current meter measurements using the Velocity-Area method (mean section) were taken at Lc1 between July and December 2006 for establishing a rating curve and hence to measure discharge (Jaramillo, 2007). A continuous estimate of suspended sediment yield (SSY) was obtained as the product of the instantaneous river discharge and the TSS. The assumption that the TSS obtained by the OBS represented that from the entire cross section was made for calculating sediment yields.

To obtain an annual sediment yield for 2006, the stage-discharge (Q) curve and the TSS-Q relationships for the rising and receding limbs of the event hydrographs obtained for the measured period were applied to the stage readings from the period January 2006 to September 2006 before the installation of the OBS, and base flow discharge and its corresponding sediment yield were subtracted from the total values.

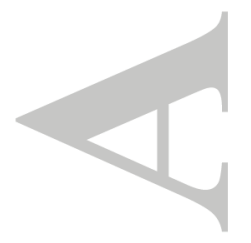

This article is protected by copyright. All rights reserved. 


\section{Peak TSS and/or suspended sediment yield measurements from subcatchments}

\section{with characteristic land uses}

We proceeded to measure TSS with the aid of an automatic water sampler at two

locations that represented LULCs with the highest soil loss per area, based on a RUSLE analysis by Jaramillo (2007). These LULCs were a quarry and bare land. The site selected to measure the quarry's emissions was the receiving Don Juan River, $800 \mathrm{~m}$ downstream from the quarry (Lc2 in Figure 1c). The second location selected (Lc3 in Figure 1c) was a concrete-lined outlet of a small subcatchment, which included a 2 ha construction site. At the time of measurement, the site had been grubbed but no construction had started.

A 6712 ISCO Portable Water Sampler was programmed to sequentially take twenty four (24) 1-litre water samples from the stream during the event, one sample each at a specified time interval and for triggering at the start of a rainfall event by a tipping bucket, ISCO 647 Raingauge, attached to it and located in a clearing nearby to each site. The water samples were then transported to the Environmental Engineering Laboratory at The University of the West Indies and tested for TSS, following the guidelines of Clesceri (1998). The sampler was first set up at the construction site between July and September 2006 where samples were taken at 10 minute intervals. It was then moved to the Don Juan River where samples were taken at 15 minute intervals, from October to December 2006.

Continuous rainfall information over the MSJRC was obtained from four (4) Rainwise raingauges deployed strategically over the catchment to capture the spatial variability of 
the storms at suitable locations (Lc2, Lc3, Lc6, Lc7), from July 2006 to October 2007.

Spatially averaged rainfall depths were estimated from the Thiessen polygon method using all the raingauges available for the study.

The study resumed in 2010, this time measuring suspended sediment yields instead of only TSS and, based on the 2006 findings, focused all measuring efforts on the quarry as the main source of suspended load. Raingauges used in this study were at sites Lc6 and Lc8. Since this time it was not possible to directly sample the Don Juan River at Lc2, as in 2006, a paired method approach (Walling \& Gregory, 1970) was used to estimate sediment yield, using the data measured by the instruments established at two sites. At the upstream site (Lc4 in Figure 1c), which was $700 \mathrm{~m}$ upstream of the mouth of the Don Juan River on the Acono River (Lc2), a water sampler took samples for TSS estimations and a Stevens Type F recorder took continuous stage values for discharge estimation. At the downstream site (Lc5 in Figure 1c), which was $100 \mathrm{~m}$ downstream of the same confluence, a set of the same instruments at Lc4 measured the same parameters. Measurements from Lc4 also provided estimates of sediment yield from the catchment upstream, which was of rugged terrain covered with dense forest.

\section{Bed composition sampling and bed load measurements}

Work by Baccard (2011) on the composition of the bed load at Lc4 and Lc5, enabled the characterization of the bed material without and with the effect of the quarry and permitted an understanding of the mobility characteristics of both types of material along the drainage network of MSJRC. For surface and sub-surface bed material, about 10 litres of sediment taken down to a depth of $0.25 \mathrm{~m}$ were extracted with a shovel. For 
surface material only, the Wolman Pebble Count method (Wolman, 1954) was

performed in conjunction with the zigzag method in 2010. The surface sediment was collected at a spacing of two boots-length measurements, from toe to heel, along a straight line at an angle to the centerline of the flow. A sediment particle at the tip of the boot was picked up and its intermediate length sized using the gravelometer.

Bed sediment load measurements at these locations were also conducted simultaneously to determine the bed load with and without the effect of the quarry. A permanent "instream installation" bed load sampler was installed in the river channel in the middle of a straight section at each location. The sampler was similar to the "unweighable pit traps" with an adjustable slot opening on its top. Its design was based on work done with Birkbeck-type bed load samplers but without a weighing device. It consisted of a rectangular $50 \mathrm{~mm}$ thick reinforced concrete box, with four equal compartments to hold four removable steel bins (Figure 3). The bins and their lids were made of $5 \mathrm{~mm}$ thick steel plate. The slot size of the lid, which could have been varied between 0 to $0.25 \mathrm{~m}$, was set as required and the lid bolted onto the bin. The river bed was excavated to install the box such that the top of the lids of the bins was leveled with the original bed elevation. The principle of this sampling is that as long as a bin is not full or removed from its location, any particle moving as bed load above the slot will be trapped in the sampler and will thus contribute to the bed load there.

Two anchor hooks provided on each bin allowed for the weighing of the bins with an industrial scale attached to a portable gantry that spanned the length of the box and could have lifted the bins clear above the water level. The bed load yield from each 
period was obtained as the difference between the weight of each empty bin measured at installation and the weight with sediments at the end of the sampling period. Further details of the equipment and the weighing procedure are given in Baccard (2011).

The testing of bed surface, subsurface and bed load samples included the analysis of grain size distribution through sieve analysis BS EN 933-1 (British Standards

Institution, 1997) and the determination of the origin of the material (natural/river vs. processed/quarry) by manual sorting. The criteria used for the differentiation were the type of material (limestone vs. quartz), the shape of the particles (sharp vs. round) and their colour (gray-blue vs. yellow-beige). Knowing that the material from the quarry consisted of distinctly sharp particles of blue limestone, it was possible to determine manually for each size class the percentage of material that originated from the quarry.

\section{RESULTS AND DISCUSSION}

\section{Measured sediment yields at MSJRC outlet}

At MSJRC outlet, 18 complete rain events with more than $1.0 \mathrm{~mm}$ of precipitation were recorded between September 2006 and January 2007 (Figure 4). For the largest five events, the peaks in discharge and sediment load had concurrent peaks with the storms. The event of November $13^{\text {th }}$ represented $32 \%$ of the total precipitation and $68 \%$ of the total sediment yield exiting the catchment within the measured period. In total, the five largest events accounted for $67 \%$ of the precipitation falling within the recorded period and $92 \%$ of the suspended sediment yield. Similar high sediment due to soil loss after high intensity and low frequency events has also been found downstream of mining areas (Evans et al., 2000). This fact highlights the importance of large events during the rainy season in the hydrological cycle of the catchment. This initial finding signals 
possible increased sediment loads from the MSJRC if the expected global

intensification of the hydrological cycle due to climate change is realized (Huntington, 2006).

On the other hand, some events with large precipitation values did not generate the expected sediment loads, such as the events of October $24^{\text {th }}$, December $12^{\text {th }}$ and January $11^{\text {th }}$. This contradiction could be explained by one or several of the following: 1) soil loss is not related to total precipitation but rather to its intensities, 2) the unique spatial location of each storm event within MSJRC; and 3) the heterogeneity of the LULCs covered by the rain events, altering the amount of soil loss and thus of sediment in the streams for events with similar $\mathrm{EI}_{30}$ values but different spatial distributions. The annual suspended sediment yield of MSJRC at Lc1 was estimated to be around 8,500 $\mathrm{Mg} \mathrm{yr}^{-1}$ (2.1 $\left.\mathrm{Mg} \mathrm{ha}^{-1} \mathrm{yr}^{-1}\right)$

\section{Emissions from identified sources (quarry, construction site, forest)}

We proceeded to measure TSS from two subcatchments containing representative areas of three of the catchment's major LULCs, namely quarrying, bare lands (construction site) and forested. The maximum TSS sample of each rain event was used as a proxy to compare suspended sediment quantities generated by the quarry and construction site at Lc2 and Lc3, respectively, to that of MSJRC outlet (Lc1) in the absence of discharge data for the first two sites (Figure 5a). With the exception of the smallest event, peak TSS emitted in the quarry subcatchment (Lc2) are larger by two orders of magnitude than those found at Lc1 which is explained by dilution (Wolman \& Schick, 1967), and by one order of magnitude than those of the construction site (Lc3). Even though for 
large events the peak TSS at Lc1 steadily increased until reaching the values

comparable with the construction site, the peak TSS at Lc2 continued to be greater than

both. Care must be exercised in assuming this same behaviour of TSS for suspended

load since the resuspension observed in the field during large rain events at Lc2 implies that in all locations a portion of the load may be originating from in-stream processes.

During the data collection campaign in 2010-2011 discharge measurements were possible so that estimations of suspended sediment yields and sediment loadings from the quarry subcatchment (Lc2) could be made. We proceeded to estimate the impact of the quarry on sediment loads by comparing suspended sediment yields upstream and downstream of the confluence of the Don Juan River (Lc2), at Lc4 and Lc5, respectively. Eight (8) sampling events for which simultaneous measurements were made at Lc4 and Lc5 were used to gauge the impact of the quarry. Yields from the quarry subcatchment $\left(\mathrm{SSY}_{2}\right)$ were estimated from a simple sediment budget. We assumed that since the land use of the Upper Acono subcatchment is almost completely dense forest, its outlet (Lc4) allowed for the estimation of values of sediment yield per unit of catchment area for "natural/pristine conditions." Also, we noted that the land cover in the Lower Acono comprises $97 \%$ of land under "natural/pristine conditions" and $3 \%$ of land occupied by the quarry. Therefore, suspended sediment yield from the quarry, $\mathrm{SSY}_{\mathrm{Q}}$, was calculated in terms of suspended sediment yield at Lc2, Lc4 and Lc5 $\left(\mathrm{SSY}_{2}, \mathrm{SSY}_{4}, \mathrm{SSY}_{5}\right)$ and their afferent areas $\left(\mathrm{A}_{2}, \mathrm{~A}_{4}, \mathrm{~A}_{5}\right)$, respectively, as:

$S S Y_{Q}=S S Y_{2}-\left(\left(A_{2}-A_{Q}\right) *\left(S S S_{4} / A_{4}\right)\right)($ Table 2$)$

Eq. 1

where 


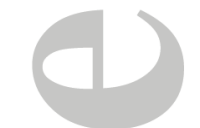

Summing the results from these eight events, SSY4 (before quarry) represented only $3 \%$ of the $\mathrm{SSY}_{5}$, providing evidence for the large contribution of sediment yield originating in the Don Juan subcatchment where the quarry is located. During these events, the quarry yielded between 2 and $49.2 \mathrm{Mg} \mathrm{ha}^{-1}$ of sediment in the stream, while the natural forest (low emitting matrix) never yielded more than $0.12 \mathrm{Mg} \mathrm{ha}^{-1}$ of suspended sediment per event. For the 8 rain events measured, it was estimated that per unit of catchment area, the quarry yielded about 487 times more sediment than the rest of the subcatchment, assumed to be mainly forest; a considerably high value when compared with other studies (Rivas et al., 2006).

When comparing the expected values of the linear regressions of each SSY at all measured locations (E[SSY]) for the range $10<\mathrm{EI}_{30}<10,000$ (Figure 5b), it can be seen that $\mathrm{E}\left[\mathrm{SSY}_{5}\right]$ and $\mathrm{E}\left[\mathrm{SSY}_{2}\right]$ are greater than $\mathrm{E}\left[\mathrm{SSY}_{1}\right]$, which in turn is greater than $\mathrm{E}\left[\mathrm{SSY}_{4}\right]$. This confirms the processes of retention of suspended sediment along the drainage network. The fact that $\mathrm{E}\left[\mathrm{SSY}_{4}\right]$ is less than $\mathrm{E}\left[\mathrm{SSY}{ }_{1}\right]$ implies that suspended sediment at MSJRC outlet is linked more with suspended sediment originating in the quarry subcatchment (and presumably the quarry) rather than with suspended sediment from the forested LULC. Additionally, the closeness of the slopes of the linear regression at Lc1 and Lc5 and the difference with that of Lc2 suggests a link between the suspended sediment yields at MSJRC outlet and the ones originating in the quarry. 
On the other hand, suspended sediment yields within the range $1<\mathrm{EI}_{30}<10$ for all locations are similar and appear to be closer to base flow conditions. It is worth noting, however, that large rain events at the quarry can produce sediment yields two orders of magnitude more than under small rain events, which again agrees with the findings of Evans (1997) on mining plots.

\section{Bed load and bed material}

Bed load measurements were taken at the two locations Lc4 (upstream) and Lc5 (downstream) on the Acono River, Figure 1c, during the period November $1^{\text {st }} 2010$ and January $7^{\text {th }} 2011$. A total of eight samples were taken at Lc4 and fourteen samples at Lc5. There were three occasions when the sampling for both stations coincided. The remaining samplings, on the other hand, covered periods of varying durations and were therefore specific for the location and time. Nevertheless, in every case the sample boxes were over filled at Lc4 and only 3 of the fourteen sampling events at Lc5 did the boxes not over fill (possibly due to very low rainfall events). This thus makes it difficult to determine the total load transported during significant events and instead can only be used to estimate lower bound sediment loadings at these locations.

The $\mathrm{d}_{90}$ collected in the sample boxes at location Lc4 was less than half the size of the $d_{90}$ for the bed surface (Table 3), which suggests that the bed shear stress developed during the sampled events were much lower than historic events. The Hjulstrom graph of mean Flow velocity vs Grain size indicates that the velocities of the main events (50 to $90 \mathrm{~cm} \mathrm{~s}^{-1}$, Table 4) were well within the range of 'erosion and transport of sand and gravel.' On comparison of the particle size distributions at Lc4 of the transported 
sediment collected with the river bed surface layer, it is seen that the maximum particle size transported is approximately equal to the $\mathrm{d}_{50}$ of the surface layer. This phenomenon is described by Wilcock \& McArdell (1997) as partial transport. Partial transport of sand and gravel mixtures (as in gravel-bed rivers) is the transport of finer fractions in much greater quantities than the coarse fractions. The sediment transport events measured in this study verifies the partial transport theory as the size distribution transported here is more closely related to the bed material than the surface material (Baccard, 2011).

When comparing the three corresponding sampling events from both sites we see that the ratio of the $\mathrm{d}_{50}$ (Lc4 to Lc5) is 1.43 and for the $\mathrm{d}_{90}$ it is 1.46 . Furthermore, the ratios of the bed surface sediments (Lc4 to Lc5) are 3.5 (Table 4). These ratios point to an abundance of finer material passing the section Lc5, which is inconsistent with that passing Lc4. Physical examination of the size, shape, colour and mineralogy of the sediments collected at the Lc4 and Lc5 locations concluded that most of the particles transported at Lc5 originated from the quarry. For the same three sampling periods, the $\mathrm{d}_{90}$ at $\mathrm{Lc5}$ averaged $16.7 \mathrm{~mm}$ and all particles of size greater than $25 \mathrm{~mm}$ were identified as originating from the natural river bed (i.e. the Acono River and the Don Juan River) (Baccard, 2011). Additionally, the fact that $70 \%$ of the particles in the size range $2.36-$ $9.5 \mathrm{~mm}$ were identified as quarry sediments supports the hypothesis that the quarry via the Don Juan River (see Figure 6) is supplying an excessive quantity of fine material to the Acono River.

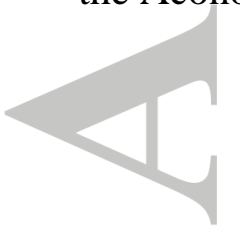


The sediment size analysis in Table 4 shows that the surface sediment, at Lc5, is very similar to that transported as bed load in the three events compared herein. Unlike the surface sediment and bed load sediment relationship at Lc4, the bed sediment at Lc5 is much finer than the bed load sediments collected for these three events. That is, the $\mathrm{d}_{50}$ and $d_{90}$ for the surface sediments are similar to those of the bed load of the three events. Furthermore, the bed sediments are much finer than the sediments collected in the sample box for these three events. It would be reasonable to suggest that the sediment transport mechanism at Lc5 could be different from that at Lc4. Whiting et al. (1988) showed that the transport of such poorly sorted sediments is in the form of bed load sheet. That is, $70 \%$ to $90 \%$ of the bed load is finer by weight (representing sand) and the coarser sediment is fine gravel. The overall morphology of this sedimentary distribution is a bed load sheet that is different from the typical ripples and dunes morphology. Considering the full range of particle size transported in this period we can conclude that at least $75 \%$ of the sediment leaving the study area at Lc5 originates from the quarry. Given the sporadic movement of sediment through a river network and the large quantity of quarry sediment exiting the Don Juan River, it is expected that if the quarrying activities continue unchecked it will arrive at the MSJRC outlet in large quantities.

\section{CONCLUSIONS}

This study indicates that the limestone quarry in the Don Juan River subcatchment of MSJRC is the largest producer of suspended sediment in terms of soil loss per unit area and probably of fraction of the total load of the basin. This statement is ratified by the sediment yield estimates obtained from measurements performed during both 2006- 
2007 and 2010-2011 campaigns. The material from the quarry also comprises a considerable amount of the bed load downstream of the quarry, particularly its finer composition. Consequently we postulate that the sediment yield (both suspended and bed load) exiting MSJRC has a high content of material from the quarry. Future management activities to reduce sediment yield from MSJRC should focus on reducing emissions from the quarry, a LULC less than $0.5 \%$ of the total catchment area but having a significantly disproportionate contribution to sediment yields. Such attention should also be given to basins with similar land use development, given the anticipated increase in intensification of the hydrological cycle from climate change.

\section{ACKNOWLEDGEMENTS}

Water Resources Agency provided invaluable assistance in maintaining the gauges and providing data for the analysis. UNESCO provided a grant for purchasing hydrologic instruments and current satellite imagery. We also acknowledge funds from NSERC which supported the research. We thank the reviewers for their invaluable comments that have substantially improved the quality of this manuscript.

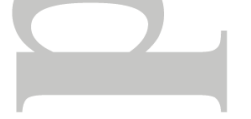

\section{REFERENCES}

Baccard M. 2011. Estimation of sediment loadings in a small steep tropical catchment impacted by quarrying activities: a case study of the Acono River catchment, Trinidad, West Indies. McGill University. Montreal, Canada. 150.

British Standards Institution. 1997. BS EN 933-1:1997 Tests for geometrical properties of aggregates. Determination of particle size distribution. Sieving method. The Inst. London, England. 1081. 
Brown C, Bally G. 1967. Land Capability Survey of Trinidad and Tobago. Map No. 4. Soils of the Northern Range of Trinidad. Government Printery, Port-of-Spain.

Cerdà A. 1999. Seasonal and spatial variations in infiltration rates in badland surfaces under Mediterranean climatic conditions. Water Resources Research 35: 319328. DOI:10.1029/98WR01659

Cerdà A. 2007. Soil water erosion on road embankments in eastern Spain. Science of the Total Environment S.I. 378: 151-155. DOI:10.1016/j.scitotenv.2007.01.041

Cerdà A, Lasanta T, 2005. Long-term erosional responses after fire in the Central Spanish Pyrenees: 1. Water and sediment yield. CATENA 60: 59-80. DOI:10.1016/j.catena.2004.09.006

Clesceri LS. 1998. Standard methods for the examination of water and wastewater. 20. ed. American Public Health Association. New York, U.S.A. 8755-3546.

Darwish T, Khater C, Jomaa I, Stehouwer R, Shaban A, Hamzé M. 2011.

Environmental impact of quarries on natural resources in Lebanon. Land Degradation \& Development 22: 345-358. DOI:10.1002/ldr.1011

Dickie JA, Parsons AJ. 2012. Eco-Geomorphological processes within grasslands, shrublands and badlands in the Semi-Arid Karoo, South Africa. Land Degradation \& Development 23: 534-547. DOI:10.1002/ldr.2170

Douglas I. 1991. Sediment Transfer and Siltation. In: The earth as transformed by human action: Global and Regional Changes in the Biosphere over the Past 300 years. Cambridge: Cambridge University Press. New York, U.S.A. 215-231. URL https://www.escholar.manchester.ac.uk/uk-ac-man-scw:3b1024

Douglas I, Lawson N. 2005. Land use: the geomorphic and land use impacts of mining. In: Rajaram V, Dutta S and Parameswaran K editor(s). Sustainable mining 
practices? a global perspective. Balkema L. 60-80. URL

https://www.escholar.manchester.ac.uk/uk-ac-man-scw:3b3549

Drysdale R, Pierotti L, Piccini L, Baldacci F. 2001. Suspended sediments in karst spring waters near Massa (Tuscany), Italy. Environmental Geology 40: 1037-1050. DOI:10.1007/s002540100311

Einstein HA, Anderson AG, Johnson JW. 1940. A distinction between bed-load and suspended load in natural streams. Transactions, American Geophysical Union 21: 628. DOI:10.1029/TR021i002p00628

Erskine W, Saynor M. 2000. Assessment of the off-site geomorphic impacts of uranium mining on Magela Creek, Northern Territory, Australia. Supervising Scientist Report 156, Camberra, Australia. NTUniprint, Darwin, Australia. 59.

Evans KG. 2000. Methods for assessing mine site rehabilitation design for erosion impact. Soil Research 38: 231-248

Evans KG, Saynor MJ, Willgoose GR, Riley SJ. 2000. Post-mining landform evolution modelling: 1. Derivation of sediment transport model and rainfall-runoff model parameters. Earth Surface Processes and Landforms 25:, 743-763. DOI:10.1002/1096-9837(200007)25:7<743::AID-ESP95>3.0.CO;2-0

Fernández C, Vega J, Jiménez E, Vieira D, Merino A, Ferreiro A, Fonturbel T. 2012. Seeding and mulching + seeding effects on post-fire runoff, soil erosion and species diversity in Galicia (NW Spain). Land Degradation \& Development 23: 150-156. DOI:10.1002/ldr.1064

Haile GW, Fetene M. 2012. Assessment of soil erosion hazard in Kilie catchment, East Shoa, Ethiopia. Land Degradation \& Development 23: 293-306.

DOI:10.1002/ldr.1082 
Haregeweyn N, Poesen J, Verstraeten G, Govers G, de Vente J, Nyssen J, Deckers J, Moeyersons J. 2013. Assessing the Performance of a Spatially Distributed Soil Erosion and Sediment Delivery Model (watem/Sedem) in Northern Ethiopia.

Land Degradation \& Development 24: 188-204. DOI:10.1002/ldr.1121

Hudson PF, Inbar M. 2012. Land Degradation and Geodiversity: Anthropogenic Controls on Environmental Change. Land Degradation \& Development 23: 307-309. DOI:10.1002/ldr.2156

Huntington TG. 2006. Evidence for intensification of the global water cycle: Review and synthesis. Journal of Hydrology 319: 83-95. DOI:10.1016/j.jhydrol.2005.07.003

Jaramillo F. 2007. Estimating and modeling soil loss and sediment yield in the MaracasSt. Joseph River Catchment with empirical models (RUSLE and MUSLE) and a physically based model (Erosion 3D). McGill University. Montreal, Canada. 134.

Lee JW, Park CM, Rhee H. 2013. Revegetation of Decomposed Granite Roadcuts in Korea: Developing Digger, Evaluating Cost Effectiveness, and Determining Dimensions of Drilling Holes, Revegetation Species, and Mulching Treatment. Land Degradation \& Development 24: 591-604. DOI:10.1002/ldr.2248

MALMRTT. 1994. M. of A., Land and Marine Resources of Trinidad and Tobago:

Feasibility study of the Caroni River Basin. Port of Spain, Trinidad and Tobago. 120.

Mandal D, Sharda VN. 2013. Appraisal of Soil Erosion Risk in the Eastern Himalayan Region of India for Soil Conservation Planning. Land Degradation \& Development 24: 430-437. DOI:10.1002/ldr.1139 
Prokop P, Poręba GJ. 2012. Soil Erosion Associated with an Upland Farming System Under Population Pressure in Northeast India. Land Degradation \& Development 23: 310-321. DOI:10.1002/ldr.2147

Qi SZ, Zhang XX. 2011. Urbanization induced environmental hazards from breakage hills in the karst geological region of Jinan City, China. Natural Hazards 56: 571-574. DOI:10.1007/s11069-010-9701-8

Rajaram V, Dutta S, Parameswaran K. 2005. Sustainable Mining Practices: A Global Perspective. Taylor \& Francis Group plc. London, UK. 297.

Renard KG. 1997. Predicting soil erosion by water $\square$ : a guide to conservation planning with the revised universal soil loss equation (RUSLE), Agriculture handbook (Washington), 0065-4612. Washington, D.C., U.S.A. 703.

Rivas V, Cendrero A, Hurtado M, Cabral M, Gimenez J, Forte L, del Rio L, Cantu M, Becker A. 2006. Geomorphic consequences of urban development and mining activities; an analysis of study areas in Spain and Argentina. Geomorphology 73: 185-206. DOI:10.1016/j.geomorph.2005.08.006

Sadeghi SHR, Kiani Harchegani M. 2012. Effects of sand mining on suspended sediment particle size distribution in Kojour Forest River, Iran. Journal of Agricultural Science and Technology 14: 1637-1646

Trimble S. 1997. Contribution of stream channel erosion to sediment yield from an urbanizing watershed. Science 278: 1442-1444.

DOI:10.1126/science.278.5342.1442

Vaezi AR, Bahrami HA, Sadeghi SHR, Mahdian MH. 2010. Spatial Variability of Soil Erodibility Factor (K) of the USLE in North West of Iran. Journal of Agricultural Science and Technology 12: 241-252 
Walling D. 1999. Linking land use, erosion and sediment yields in river basins.

Hydrobiologia 410, 223-240. DOI:10.1023/A:1003825813091

Walling DE. 1983. The sediment delivery problem. Journal of Hydrology 65: 209-237.

DOI:10.1016/0022-1694(83)90217-2

Walling DE, Gregory KJ. 1970. The measurement of the effects of building construction on drainage basin dynamics. Journal of Hydrology 11: 129-144. DOI:10.1016/0022-1694(70)90099-5

Wang YQ, Shao MA. 2013. Spatial Variability of Soil Physical Properties in a Region of the Loess Plateau of Pr China Subject to Wind and Water Erosion. Land Degradation \& Development 24: 296-304. DOI:10.1002/ldr.1128

Whiting PJ, Dietrich WE, Leopold LB, Drake TG, Shreve RL. 1988. Bedload sheets in heterogeneous sediment. Geology 16: 105-108. DOI:10.1130/00917613(1988)016<0105:BSIHS >2.3.CO;2

Wilcock PR, McArdell BW. 1997. Partial transport of a sand/gravel sediment. Water Resources Research 33: 235-245. DOI:10.1029/96WR02672

Wischmeier WH, Smith DD. 1978. Predicting rainfall-erosion losses — a guide for conservation planning. Agricultural Handbook 537. Washington, U.S.A. 58.

Wolman MG. 1954. A method of sampling coarse river-bed material. Transactions, American Geophysical Union 35: 951. DOI:10.1029/TR035i006p00951

Wolman MG. 1967. A Cycle of Sedimentation and Erosion in Urban River Channels. Geografiska Annaler. Series A, Physical Geography 49: 385-395. DOI:10.2307/520904 
Wolman MG, Schick AP. 1967. Effects of construction on fluvial sediment, urban and suburban areas of Maryland. Water Resources Research 3: 451-464. DOI:10.1029/WR003i002p00451

Yitbarek T.w, Belliethathan S, Stringer Lc. 2012. The onsite cost of gully erosion and cost-benefit of gully rehabilitation: A case study in Ethiopia. Land Degradation \& Development 23: 157-166. DOI:10.1002/ldr.1065

Zhao G, Mu X, Wen Z, Wang F, Gao P. 2013. Soil Erosion, Conservation, and EcoEnvironment Changes in the Loess Plateau of China. Land Degradation \& Development 24: 499-510. DOI:10.1002/ldr.2246

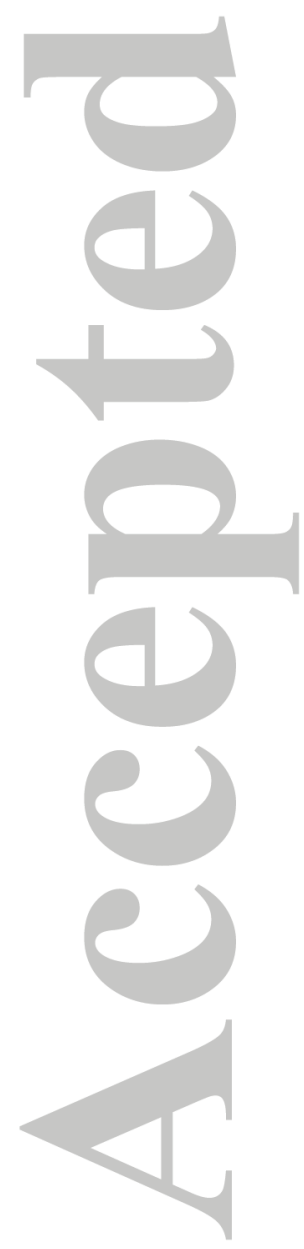


Table 1. Locations of gauging stations for the sediment yield study.

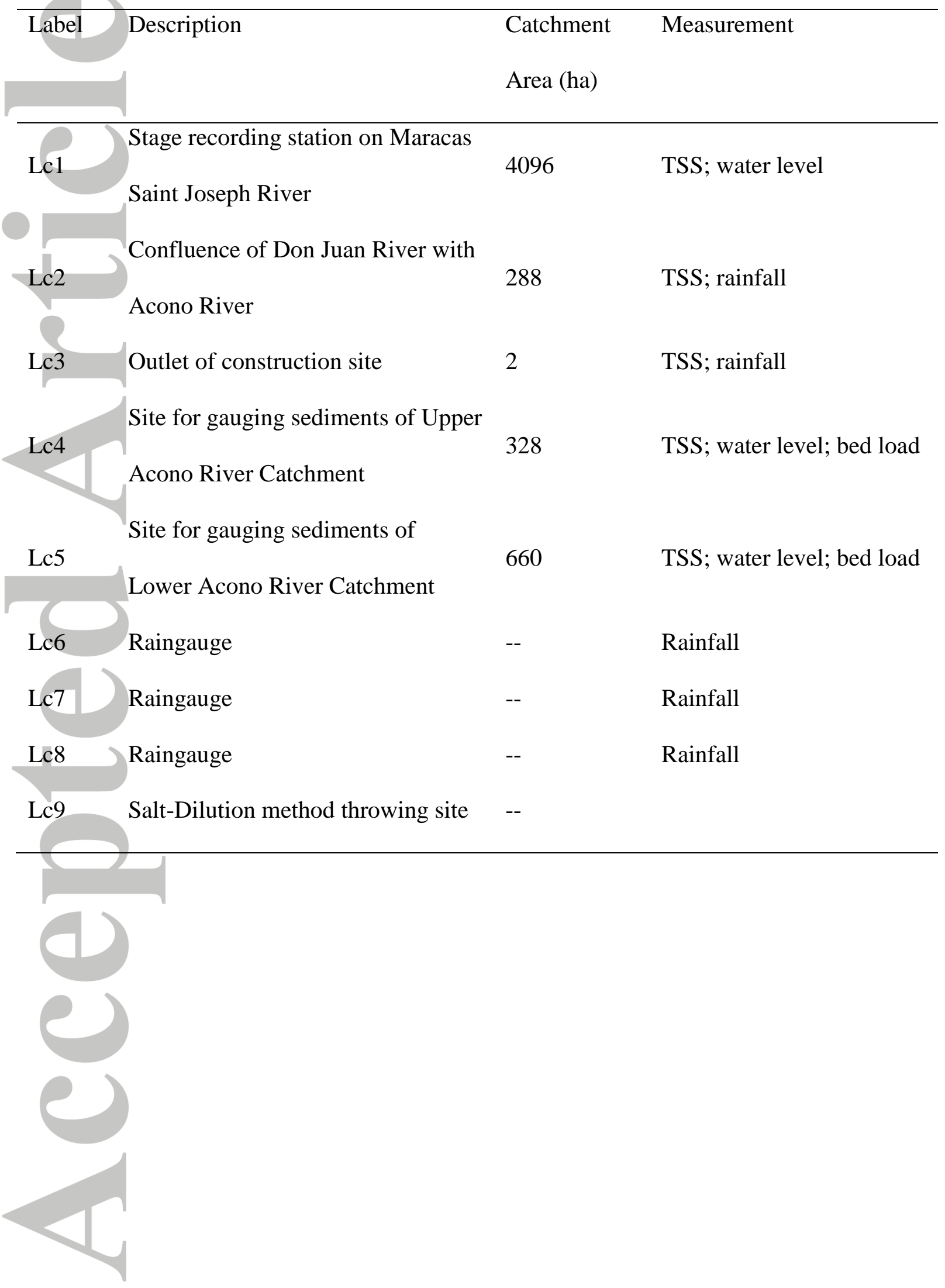




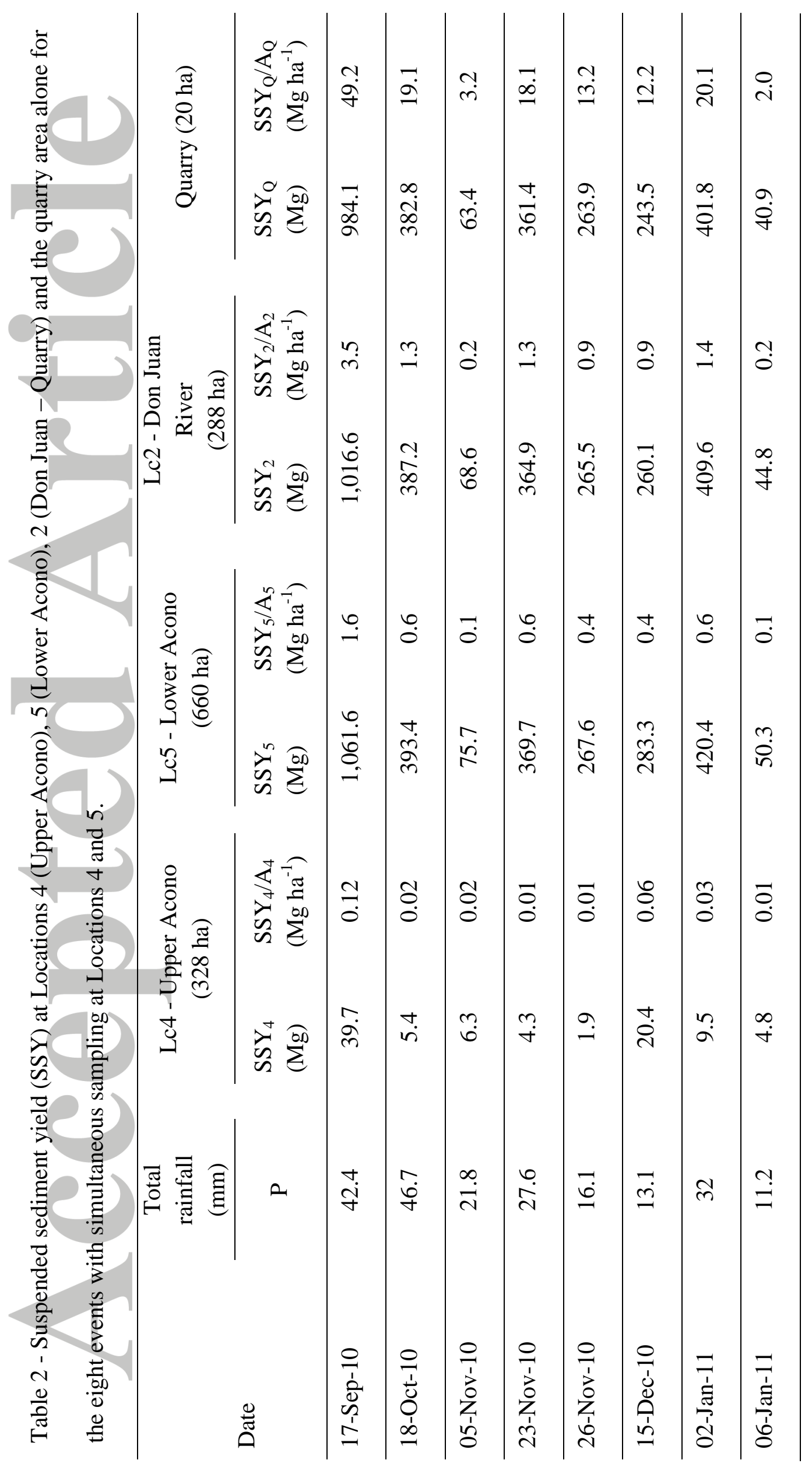

This article is protected by copyright. All rights reserved. 
Table 3 - Characteristic diameters of the river bed material and the sediment collected in the bed load samplers Upstream and Downstream of the quarry's influence (Lc4 and Lc5, respectively).

\begin{tabular}{|c|c|c|c|c|c|c|}
\hline & & $\begin{array}{c}\mathrm{d}_{35} \\
(\mathrm{~mm})\end{array}$ & $\begin{array}{c}\mathrm{d}_{50} \\
(\mathrm{~mm})\end{array}$ & $\begin{array}{c}\mathrm{d}_{65} \\
(\mathrm{~mm})\end{array}$ & $\begin{array}{c}\mathrm{d}_{84} \\
(\mathrm{~mm})\end{array}$ & $\begin{array}{c}\mathrm{d}_{90} \\
(\mathrm{~mm})\end{array}$ \\
\hline & $\begin{array}{l}\text { River bed material (manual } \\
\text { sampling) }\end{array}$ & 10 & 19.5 & 31 & 54 & 62 \\
\hline $\begin{array}{l}\text { Lc4 - Upper } \\
\text { Acono }\end{array}$ & $\begin{array}{l}\text { Sediment collected in bed load } \\
\text { sampler (average over } 72 \\
\text { samples) }\end{array}$ & 4.3 & 7 & 11.3 & 21 & 26.5 \\
\hline & $\begin{array}{l}\text { Ratio bed material size / bed } \\
\text { load size }\end{array}$ & 2.3 & 2.8 & 2.7 & 2.6 & 2.3 \\
\hline \multirow{3}{*}{$\begin{array}{l}\text { Lc5 - Lower } \\
\text { Acono }\end{array}$} & $\begin{array}{l}\text { River bed material (manual } \\
\text { sampling) }\end{array}$ & 3 & 5.5 & 8.5 & 15 & 18 \\
\hline & $\begin{array}{l}\text { Sediment collected in bed load } \\
\text { sampler (average over } 168 \\
\text { samples) }\end{array}$ & 1.8 & 3 & 4.9 & 9 & 11.4 \\
\hline & $\begin{array}{l}\text { Ratio bed material size / bed } \\
\text { load size }\end{array}$ & 1.7 & 1.8 & 1.7 & 1.7 & 1.6 \\
\hline
\end{tabular}


Table 4 - Bed sediment size statistics and flow characteristics at: a. upstream (Lc4); b. downstream (Lc5) sampling stations; and c. comparison of values at Lc4 and Lc5.

a. Upstream Site (Lc4)

\begin{tabular}{|c|c|c|c|c|c|}
\hline \multicolumn{2}{|c|}{ Sampling period } & \multicolumn{2}{|c|}{$\begin{array}{c}\text { Diameter particles } \\
\text { sampled }(\mathrm{mm})\end{array}$} & \multirow{2}{*}{$\begin{array}{c}\text { Peak discharge } \\
\left(\mathrm{m}^{3} \mathrm{~s}^{-1}\right)\end{array}$} & \multirow{2}{*}{$\begin{array}{l}\text { Velocity } \\
\left(\mathrm{cm} \mathrm{s}^{-1}\right)\end{array}$} \\
\hline Start & End & $\mathrm{d}_{50}$ & $\mathrm{~d}_{90}$ & & \\
\hline $1-\mathrm{Nov}$ & 4-Nov & 4.7 & 21.9 & 1.4 & 60 \\
\hline 4-Nov & 8-Nov & 8.7 & 30.7 & 2.0 & 67 \\
\hline 25-Nov & 29-Nov & 5.4 & 20.9 & 0.8 & 50 \\
\hline \multicolumn{2}{|c|}{ Size Average (SA) } & 6.27 & 24.5 & & \\
\hline \multirow{2}{*}{\multicolumn{2}{|c|}{$\begin{array}{l}\text { *Surface Sediment (SS) } \\
\text { *Bed Sediment (BS) } \\
\underline{\text { Size Ratio }}\end{array}$}} & 19.5 & 62.0 & & \\
\hline & & 7.0 & 26.5 & & \\
\hline \multicolumn{2}{|l|}{ SS/SA } & 3.11 & 2.53 & & \\
\hline \multicolumn{2}{|l|}{$\mathrm{BS} / \mathrm{SA}$} & 1.12 & 1.08 & & \\
\hline
\end{tabular}

\section{b. Downstream Site (Lc5)}

\begin{tabular}{lccccc}
\hline \multicolumn{2}{c}{ Sampling period } & \multicolumn{2}{c}{$\begin{array}{c}\text { iameter particles } \\
\text { sampled }(\mathrm{mm})\end{array}$} & $\begin{array}{c}\text { Peak discharge } \\
\left(\mathrm{m}^{3} \mathrm{~s}^{-1}\right)\end{array}$ & $\begin{array}{c}\text { Velocity } \\
\left(\mathrm{cm} \mathrm{s}^{-1}\right)\end{array}$ \\
\hline Start & End & $\mathrm{d}_{50}$ & $\mathrm{~d}_{90}$ & & \\
\hline 1-Nov & 4-Nov & 4.1 & 19.5 & 6.5 & 89 \\
4-Nov & 8-Nov & 5.5 & 20.1 & 4.6 & 80 \\
25-Nov & 30-Nov & 3.5 & 10.7 & 2.5 & 65 \\
\hline Size Average (SA) & $\mathbf{4 . 4}$ & $\mathbf{1 6 . 8}$ & & \\
\hline & & & & \\
*Surface Sediment (SS) & 5.5 & 18.1 & & \\
*Bed Sediment (BS) & 3.0 & 11.4 & & \\
Size Ratio & & & & \\
SS/SA & 1.26 & 1.07 & & \\
BS/SA & 0.69 & 0.68 & & \\
\hline
\end{tabular}

c. Comparison of Le4 with Le5

\begin{tabular}{lcc}
\hline SS Sediment (Lc4/Lc5) & 3.5 & 3.4 \\
SA Sediment (Lc4/Lc5) & 1.4 & 1.46
\end{tabular}

* from Table 3 


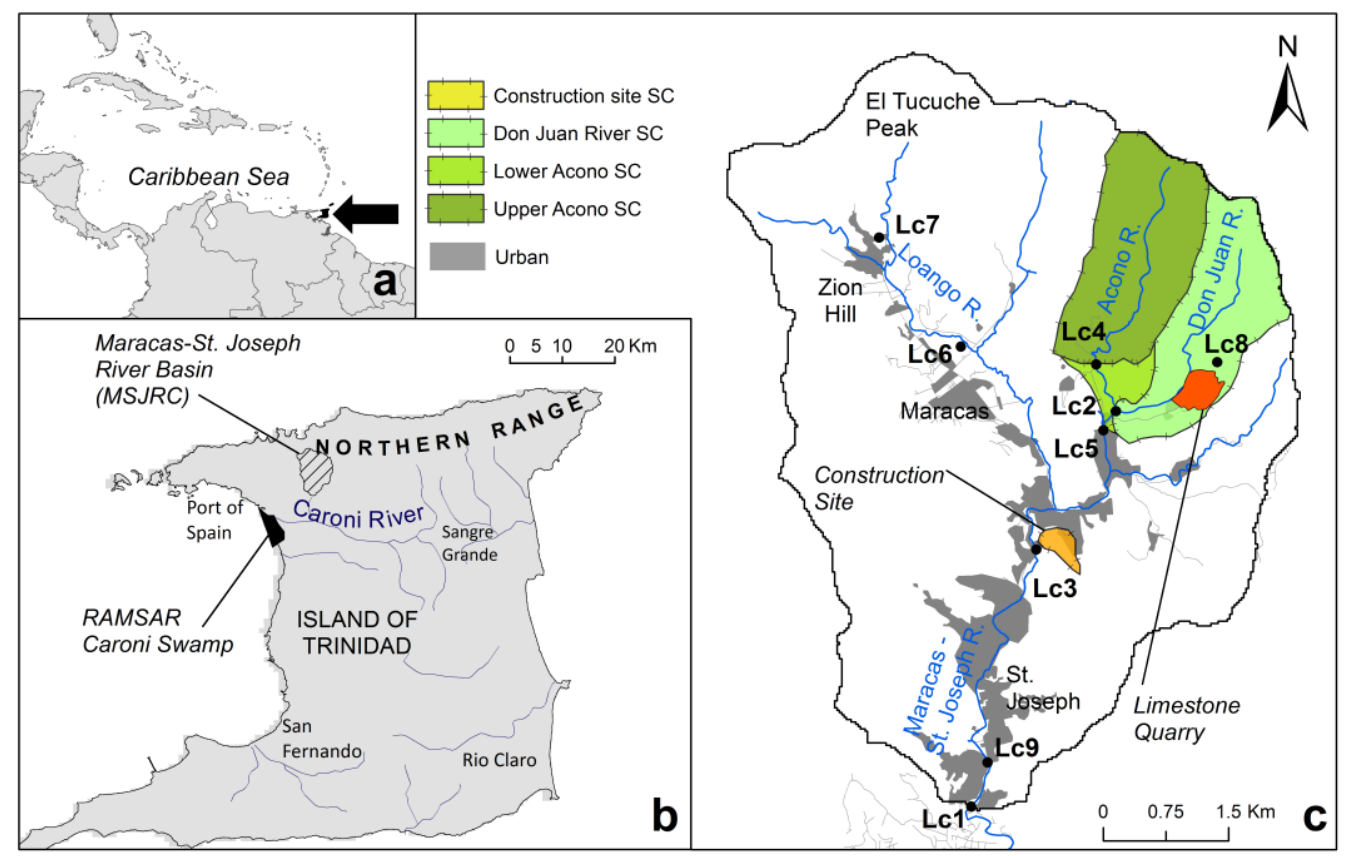

Figure 1. a. Geographical Location of Trinidad and Tobago; b. The Maracas-Saint Joseph River Catchment's (MSJRC) location in Trinidad; c. The MSJRC and its studied subcatchments, instrumentation and sampling sites numbered from Lc1 to Lc9 (see Table 1).

This article is protected by copyright. All rights reserved. 


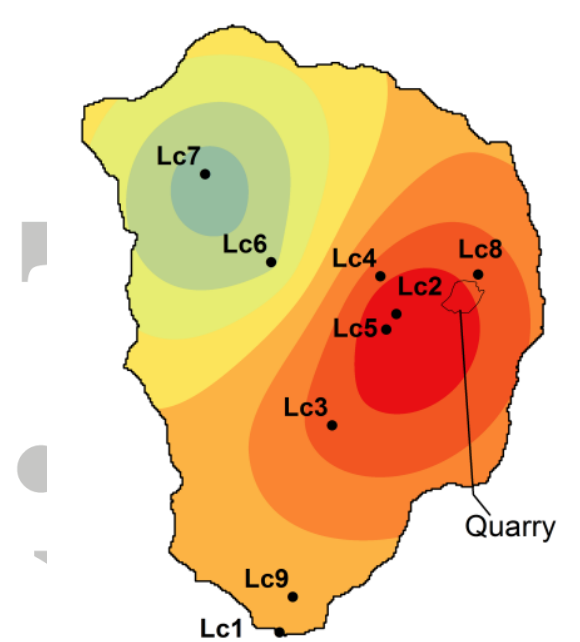

\section{$\mathrm{El}_{30}\left(\mathrm{MJ} \mathrm{mm} \mathrm{ha}{ }^{-1} \mathrm{yr}^{-1}\right)$}

$0-80$

$81-200$

$201-400$

$401-600$

$\square 601-800$

$801-1,000$

$1,001-1,200$

$1,201-1,400$

$1,401-1,600$

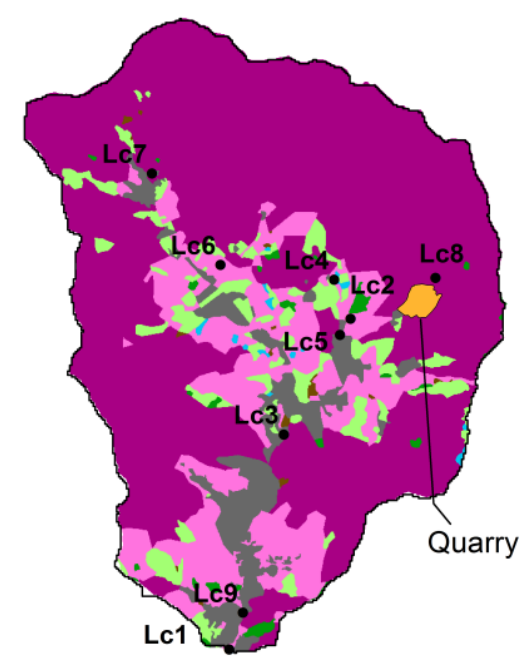

Land Use / Land Cover

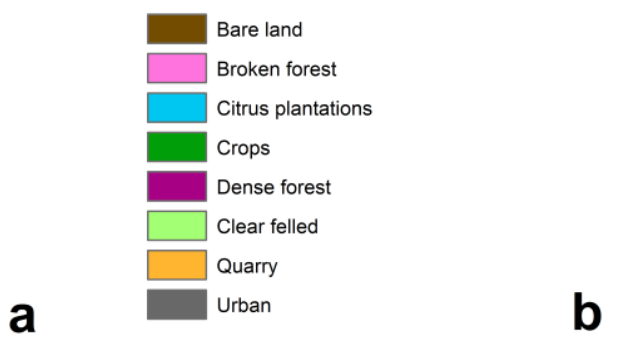

a

b

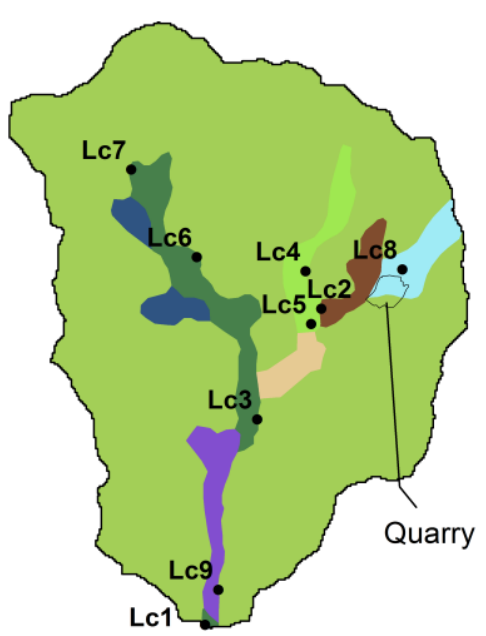

Soil Types

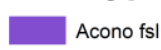

Anglais clay

Guanapo sc

La Pastora sc - Platanal clay

Maracas scl - Matelot scl

River estate fsl

Santa Cruz fsl

St. Joseph fsl

Figure 2. a. Sum of the products of rainfall intensity and duration $\left(\mathrm{EI}_{30}\right)$ based on collected rain information for 16 events during the period September 2006 and January 2007; b. Land Use/Land Covers (LULC)s; and c. soil types within the MSJRC. 

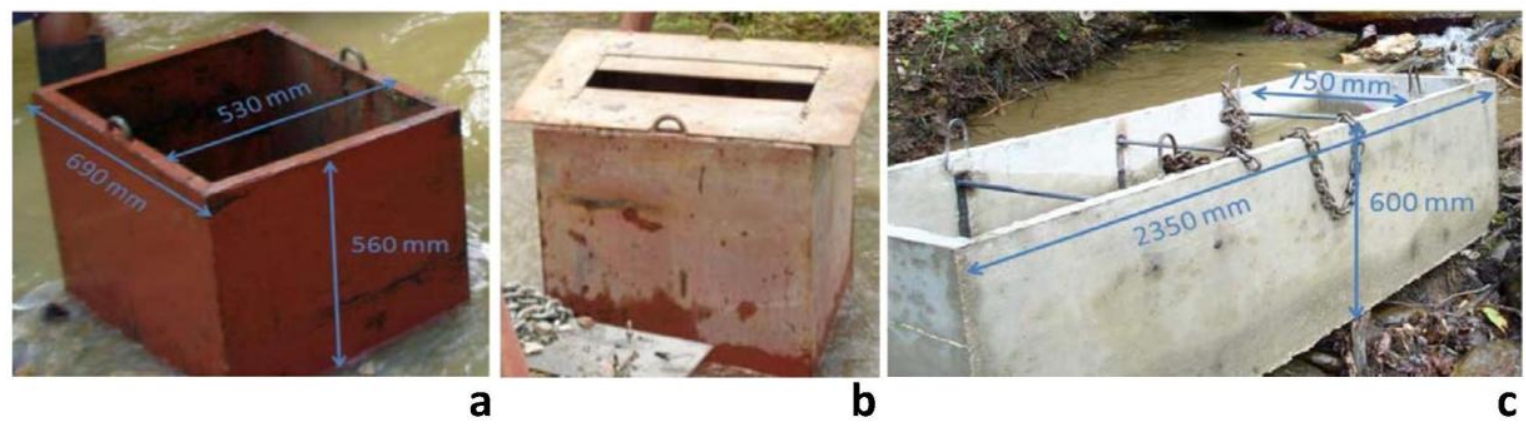

Figure 3. Bed load sampler with dimensions of bins and concrete box

a. bin without lid; b. bin with lid; c. prior to installation in river bed.

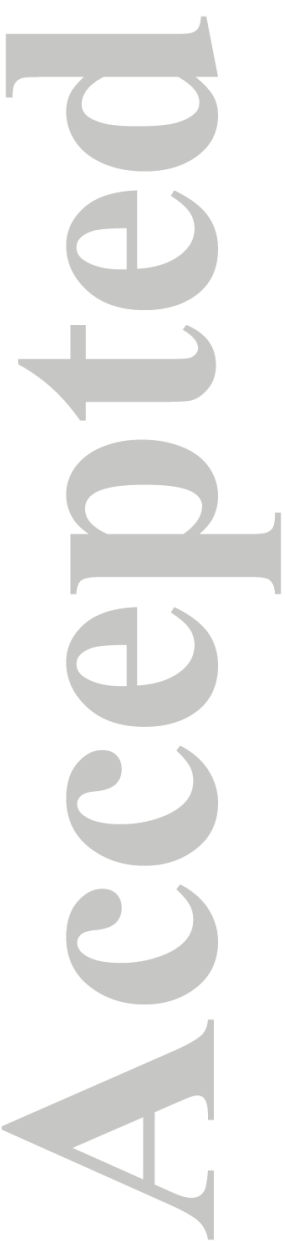

This article is protected by copyright. All rights reserved. 


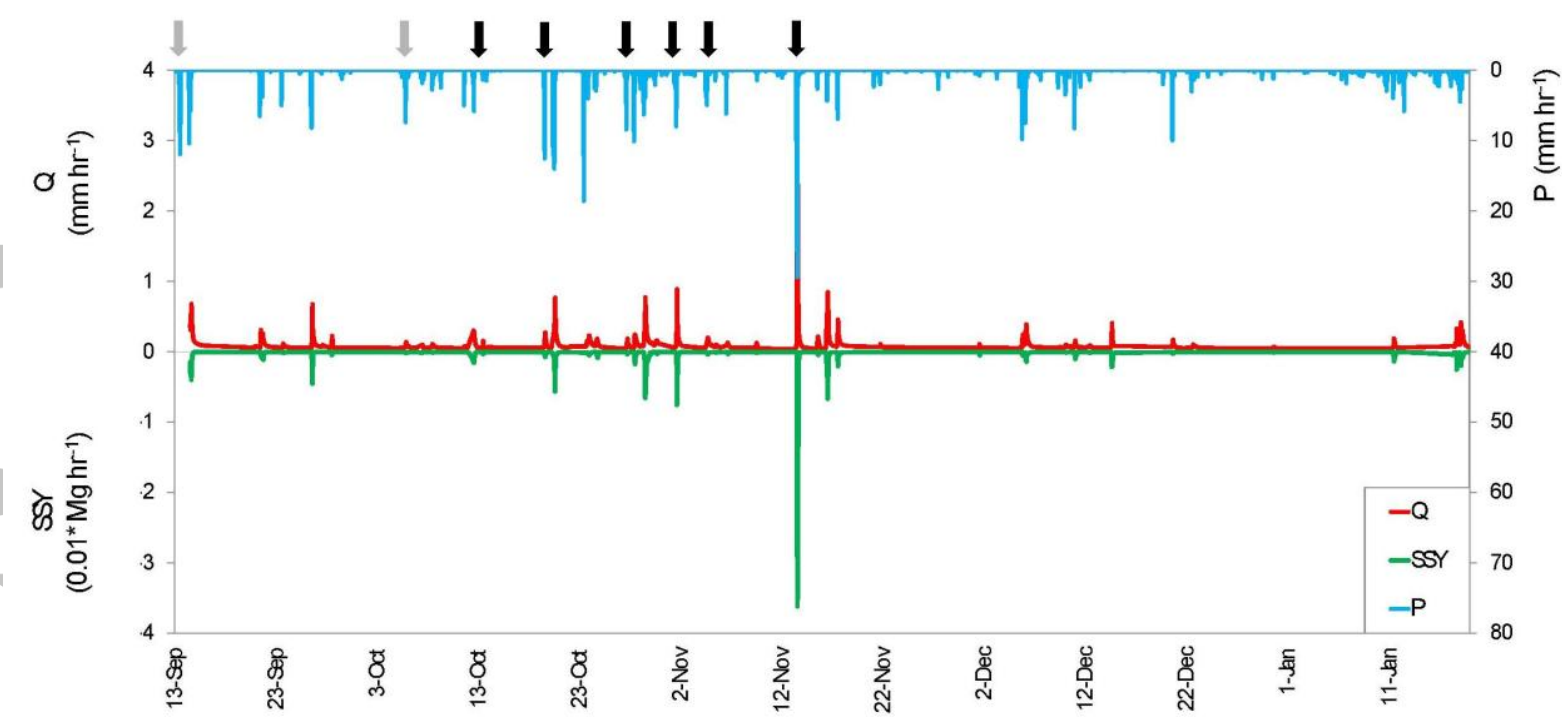

Figure 4. Time series of precipitation $\left(\mathrm{P}\right.$ in $\left.\mathrm{mm} \mathrm{hr}^{-1}\right)$, discharge $\left(\mathrm{Q}\right.$ in $\left.\mathrm{mm} \mathrm{hr}^{-1}\right)$ and suspended sediment yield (SSY in $\mathrm{Mg} \mathrm{hr}^{-1}$ ) for the MSJRC during the period from September 2006 to January 2007. $\mathrm{P}$ is calculated by Thiessen polygon procedure from the four rain stations available in the 2006-2007 campaign. Q and SSY are measured at the outlet of the MSJRC (Lc 1). Black and gray arrows highlight, respectively, the events when Total Suspended Solids (TSS) were measured at the Confluence of Don Juan River with Acono River (Lc2) and at the construction site (Lc3), respectively. Only two gray arrows are shown since the remaining 5 occurred before the period shown. 

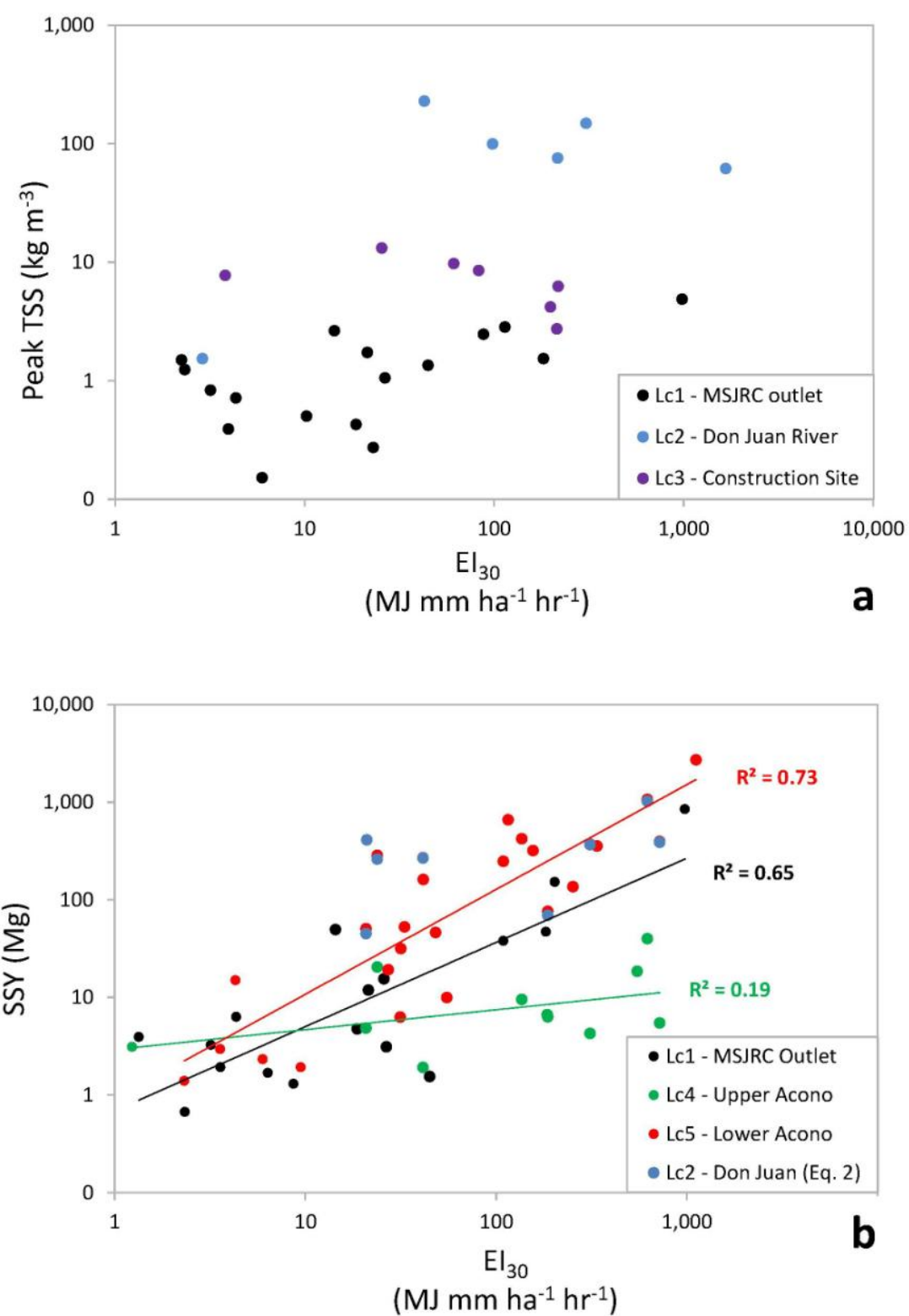

Figure 5. a. Peak Total Suspended Solids (TSS) for all storm events measured at the Construction site (Lc3), Don Juan River (Quarry) (Lc2) and MSJRC outlet (Lc1) obtained in the measuring campaign 2006-2007.

b. Log-log plots of suspended sediment yield (SSY) vs. parameter $\mathrm{EI}_{30}$. For comparison purposes, expected values from suspended yield exponential regression lines (E[SSY]) are plotted for all locations except Lc2, since real measurements were not taken at this site. SSY 1 was obtained in the measuring campaign 2006-2007, $\mathrm{SSY}_{4}$ and $\mathrm{SSY}_{5}$ in the measuring campaign 2010-2011, and SSY 2 calculated from $\mathrm{SSY}_{4}$ and $\mathrm{SSY}_{5}$ with Eq. 2. 


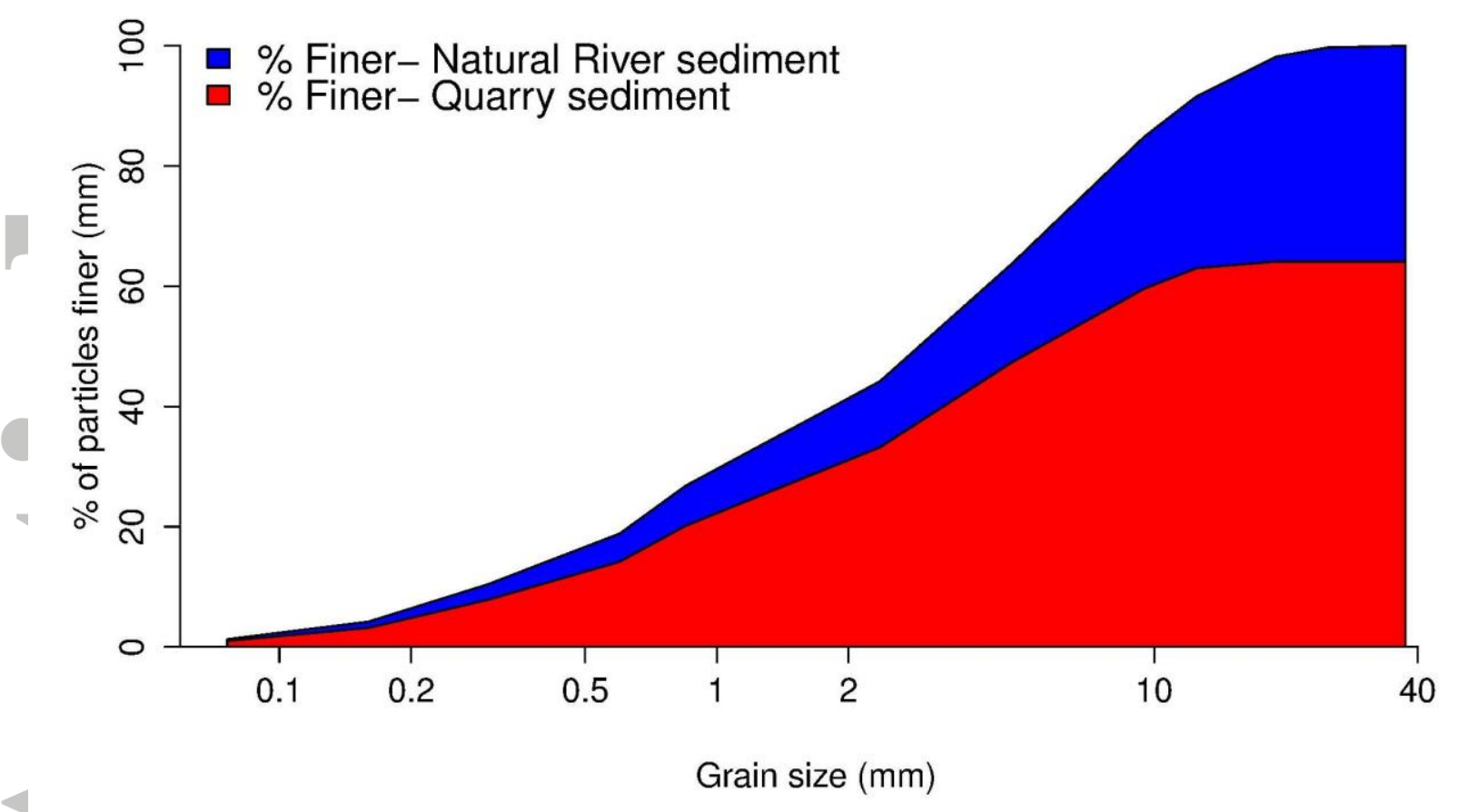

Figure 6. Size distribution of the sediment collected in the bed load sampler at Lc5 during the sampling period of Dec $13^{\text {th }}, 2010$ for material from the quarry (red) and from the natural bed of the river (blue).

This article is protected by copyright. All rights reserved. 